DOI 10.37882/2223-2982.2021.04.20

\title{
ЛИЧНОСТНО-ОРИЕНТИРОВАННЫЙ ПОДХОД В ОБУЧЕНИИ УЧАЩИХСЯ 5-6 КЛАССОВ
}

\section{PERSONALLY-ORIENTED APPROACH IN TEACHING STUDENTS 5-6 CLASSES \\ E. Luchnikova}

Summary: The article discusses a personality-oriented approach to learning, the concept of personality. The importance of the approach in the educational environment is shown on the example of educational practice. The psychological and pedagogical conditions for the development of personality are designated as an integral part in the content of education. A content analysis of the definition of "personalityoriented approach" has been made, criteria of a personality-oriented approach are outlined. The principles of the personality-oriented approach, the conditions of personality development during the lesson are considered.

Keywords: personality-oriented approach, personality, educational environment, principles of personality-oriented approach.
$\mathrm{H}$ а сегодняшний день перед образовательными учреждениями стоит задача сформировать и воспитать личность, соответствующую требованиям Федерального государственного образовательного стандарта основного общего образования (далее ФГОС оОО) [1]. Мы, ориентируясь на требования стандарта, рассмотрим личностно-ориентированный подход к обучению учащихся.

Идея личностно-ориентированного подхода в нашей стране разрабатывалась с начала 80-х годов XX века К.А. Абульхановой-Славской, И.А. Алексеевым, Ш.А. Амонашвили, Е.В. Бондаревской, С.В. Кульневичем, А.А. Орловым, В.В. Сериковым, И.С. Якиманской и др. в связи с трактовками воспитания как субъект-субъектного процесса.

Рассматривая понятие личность, обратимся к анализу литературы. Системное социальное качество рассматривается А.В. Петровским при трактовке понятия личности, где он также указывает, как в объективной деятельности и общении оно приобретается от индивида, и характеризует уровень и качество социальных отношений [5].

Личность как сложный феномен общественной жизни трактуется А.Г. Ковалевым, где, с одной стороны, он видит личность как продукт социально-исторического развития, с другой - как деятель общественного развития. [8].

\author{
Лучникова Елена Валерьевна \\ Учитель, МАОУ «Гимназия № 5»; аспирант, ФГБОУ ВО \\ «Пермский государственный \\ гуманитарно-педагогический университет» \\ alisaflower@yandex.ru
}

Аннотация: В статье рассмотрен личностно-ориентированный подход в обучении, понятие личность. Показана значимость подхода в образовательной среде на примере образовательной практики. Обозначены психолого-педагогические условия для развития личности, как неотъемлемая часть в содержании образования. Сделан контент-анализ дефиниции «личностно-ориентированный подход», обозначены критерии личностно-ориентированного подхода. Рассмотрены принципы личностно-ориентированного подхода, условия развития личности во время урока.

Ключевые слова: личностно-ориентированный подход, личность, образовательная среда, принципы личностно-ориентированного подхода.

С.М. Гульянц считает, что личность - это особое качество, которое человек приобретает в обществе, воплощает в себе систему отношений, имеющих социальный характер, которые вписываются в сферу бытия человека как его системное качество [3].

При обучении, ориентированном на ученика 5-6 класса, акцент смещается с учителя на ученика. Подход, ориентированный на учащихся, включает активное обучение, при котором учащиеся решают проблемы, отвечают на вопросы, самостоятельно формулируют вопросы, обсуждают, объясняют, обсуждают или проводят мозговой штурм во время урока; совместное обучение, при котором учащиеся работают в группах над проблемами и проектами в образовательной среде, которая обеспечивает как позитивную взаимозависимость, так и индивидуальную ответственность; индуктивное обучение и преподавание, при котором учащимся сначала ставятся задачи (вопросы или проблемы), а обучение на уроках происходит в контексте решения проблем. Чем понятнее обозначена цель на уроке, тем меньше трудностей возникает у учащихся. При возможности обсуждения вариантов решения проблем, учащимся дается возможность задавать уточняющие или проблематизирующие вопросы, где установка от учителя такова: «Нет неправильных, плохих вопросов, есть незаданный вопрос». При таких установках учащиеся 5-6 классов проявляют себя на уроках более активно, открыто без чувства страха быть непонятым. Используя технику «мозговой штурм», уча- 
щиеся способны найти ядро поставленной проблемы и представить более рациональные пути решения.

Рассмотрим мнение И.С. Якиманской, которая пишет, что учащийся признается центральной фигурой личностно-ориентированного образования, цель которого - создание психолого-педагогических условий для его развития как личности. В то же время функциональные обязанности учителя и психолога встроены в содержание образования, которые составляют содержание и направленность этого образования как психологической и дидактической системы [8, с.15].

И.С. Якиманская утверждает, что при личностно-ориентированном подходе наличие индивидуальных различий у детей является необходимым условием достижения поставленной цели - обеспечить развитие каждого ученика как уникальной личности. Для этого нужна образовательная среда, вся практическая реализация которой подчинена целям и ценностям этого образования. В сформированной соответствующей образовательной среде учащиеся проявляют индивидуальное самовыражение; стимул к развитию исходя из индивидуальных интересов и потребностей; становление личностных качеств, необходимых для жизни в современном динамично развивающемся обществе [7, с. 33]. Обучаясь в образовательной среде, которая способствует развитию индивидуальных качеств личности, учащиеся становятся более гибкими и приспособленными к быстро меняющимся условиям в мире.

Помимо индивидуальных различий, самовыражения и интересов необходимо обеспечивать личностно-смысловое развитие учащихся. Так, Е.В. Бондаревская предложила культурологическую модель личностно-ориентированного образования, согласно которой ученик развивается не только как субъект познания, субъект жизни, но и как субъект культуры - ее носитель, хранитель, пользователь, творец [2]. С одной стороны, Е.В. Бондаревская говорит о повышении качества образования, которое зависит от государственной политики в образовании, с другой стороны, о переосмыслении задач воспитания, где познавательные и творческие способности учащихся развиваются с переориентацией на личность. На сегодняшний день в образовательных учреждениях ведется непрерывная работа по повышению качества образования за счет пересмотра формата проведения уроков и вовлечения учащихся в деятельность во время урока.

Существует ряд принципов в личностно-ориентированном подходе, В.А. Петровский их представляет следующим образом: вариативность, синтез интеллекта, аффекта и действия, а также приоритетность старта. Он объясняет эти принципы следующим образом:

- Вариативность: использование не однотипных, одинаковых для всех, а разных моделей обучения в зависимости от индивидуальных особенностей детей и их опыта. В этом случае ответственность за этот принцип несут взрослые.

- Синтез: это технологии, которые вовлекают учащихся в процесс обучения, совместных действий и эмоционального исследования мира.

- Старт: вовлечение детей в более приятные, близкие, предпочтительные для них занятия, создание благоприятных условий для дальнейшего изучения предмета [6].

Рассмотренные принципы в личностно-ориентированном подходе по мнению В.А. Петровского смогут обеспечить качественный рост в развитии воли и нравственности учащихся, эмоционального устремления личности и познавательных способностей. В ходе реализации данных принципов необходимо учитывать определенные условия в образовательном процессе. Если во время организации урока создана благоприятная, доброжелательная атмосфера, то результат у учащихся будет всегда отличным.

Согласно анализа теории и практики, можно представить дефиницию «личностно-ориентированного подхода» в виде таблицы (табл.1).

Контент - анализ дефиниции «личностно-ориентированный подход» позволяет увидеть разные критерии в виде условий, образовательной среды, учебной ситуа-

Контент - анализ понятия «личностно-ориентированный подход»

\begin{tabular}{|l|c|l|l|l|l|}
\hline Критерий & $\begin{array}{l}\text { Условия для раскрытия } \\
\text { индивидуальных воз- } \\
\text { можностей }\end{array}$ & $\begin{array}{l}\text { Образовательная } \\
\text { седа, порождающая } \\
\text { индивидуальное само- } \\
\text { выражение }\end{array}$ & $\begin{array}{l}\text { Учебная ситуация, } \\
\text { востребованная } \\
\text { учащимися }\end{array}$ & $\begin{array}{l}\text { Индивидуальные раз- } \\
\text { личия среди учащихся }\end{array}$ & $\begin{array}{l}\text { Роль учителя, стиму- } \\
\text { лирующего тенденции } \\
\text { к личностному росту } \\
\text { учащихся }\end{array}$ \\
\hline Карл Р. Роджерс & + & + & & + \\
\hline И.С. Якиманская & + & + & & + \\
\hline В.В. Сериков & + & + & & + \\
\hline В.А. Петровский & + & + & & + \\
\hline
\end{tabular}


ции, индивидуальных различий учащихся, роли учителя.

При личностно-ориентированном подходе развитие личности происходит во взаимодействии форм общения, познания, совместной деятельности; возникает сознательное отношение и сохраняется интерес к предмету. Сохраняя интерес к предмету, достигаются высокие показатели качества обучения учащихся, что является немаловажным в образовательном процессе.

Принимая во внимание интересы государства в развитии учащихся в образовательных учреждениях, применяя личностно-ориентированный подход в образовательном процессе, мы выявляем и развиваем индивидуальные способности и интересы учащихся при изучении предметов школьной программы.

Таким образом, личностно-ориентированный подход важен для формирования личности, учитывая требования стандарта подход реализуется в образовательном процессе, ориентируясь не только на воспитание, но и на высокие результаты в обучении учащихся.

\section{ЛИТЕРАТУРА}

1. Федеральный государственный образовательный стандарт основного общего образования (Утвержден приказом Министерства образования и науки Российской Федерации от 17 декабря 2010 г. № 1897) http://standart.edu.ru/catalog.aspx?Catalogld=2588

2. Бондаревская Е.В. Теория и практика личностно-ориентированного образования / Е.В. Бондаревская. - Ростов-на-Дону: Изд-во Ростовского пед. университета, 2000. - 352 c.

3. Гульянц С.М. Понятийно-терминологический тезаурус в области теории реализации личностно-ориентированного подхода в обучении [Тескт] / С.М. Гульянц // Вестник КГУ им Н. А. Некрасова. - 2008. - Том 14. - С. 4-8.

4. Ковалёв А.Г. Психология личности / А.Г. Ковалёв. - М.: Просвещение, 1969. - 391 с.

5. Петровский А.В. Быть личностью / А.В. Петровский. - М.: Педагогика, 1990. - 112 с.

6. Петровский В.А. Личность в психологии: парадигма субъектности. - Ростов-на-Дону: Изд-во «Феникс», 1996. - 512 с.

7. Якиманская И.С. Изучение личности ученика в образовательном процессе [Тескт] / И.С. Якиманская // Теоретическая и экспериментальная психология.2010. - Т.3 №1. - С. 32-38.

8. Якиманская И.С. Личностно-ориентированное обучение в современной школе / И.С. Якиманская. - М.: Изд. фирма «Сентябрь», 1996. - 96 с.

() Лучникова Елена Валерьевна (alisaflower@yandex.ru).

Журнал «Современная наука: актуальные проблемы теории и практики»

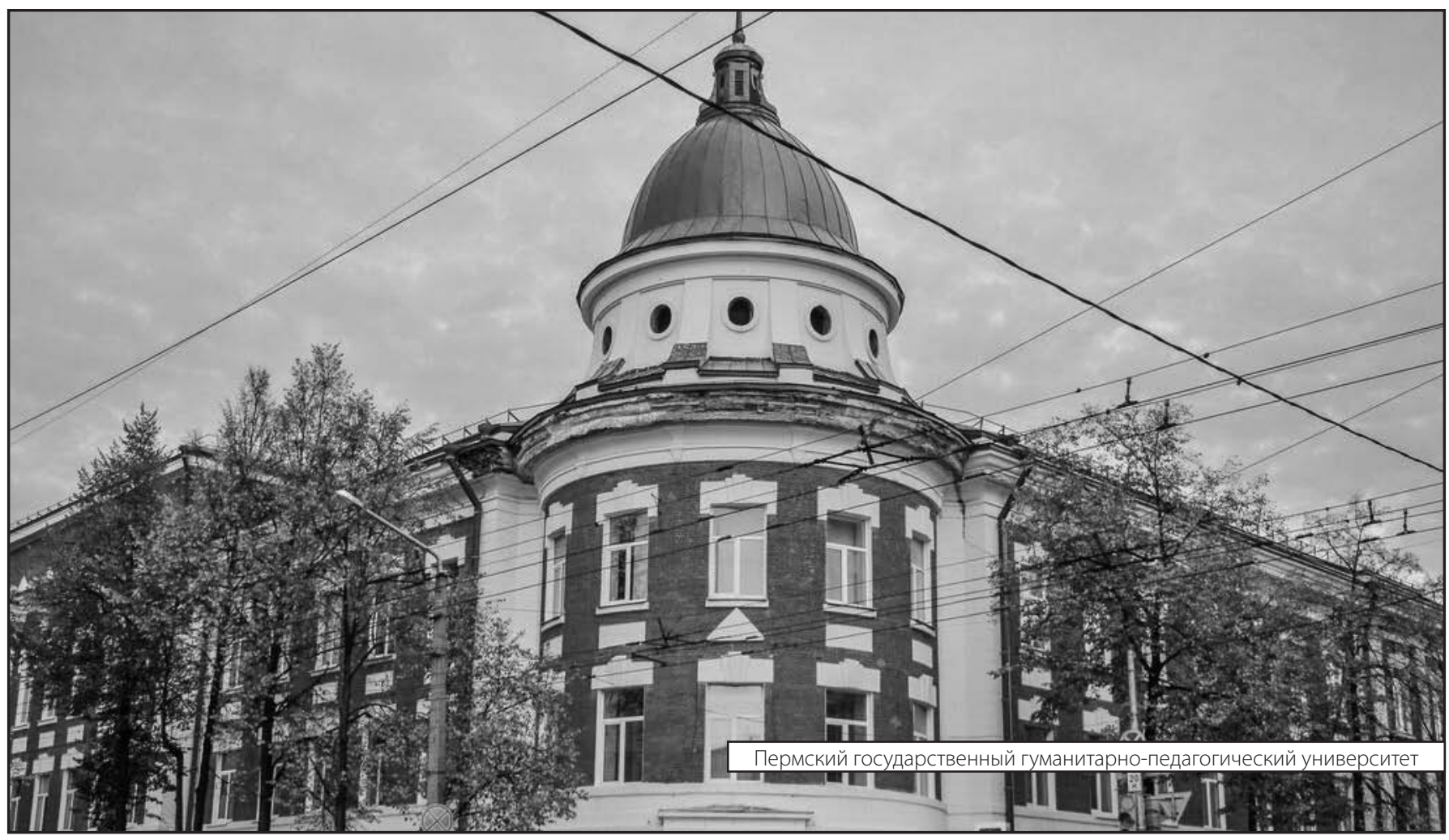

